\title{
Re-evaluating the role of natural killer cells in innate resistance to herpes simplex virus type I William P Halford ${ }^{* 1}$, Jennifer L Maender ${ }^{2}$ and Bryan M Gebhardt ${ }^{3}$
}

\begin{abstract}
Address: ${ }^{1}$ Dept of Veterinary Molecular Biology, Montana State University, Bozeman, MT, USA, 2Dept of Dermatology, Baylor College of Medicine, Houston, TX, USA and ${ }^{3}$ Dept of Ophthalmology, Louisiana State University Health Sciences Center, New Orleans, LA USA

Email: William P Halford* - halford@montana.edu; Jennifer L Maender - jmaender@houston.rr.com; Bryan M Gebhardt -bgebha@lsuhsc.edu

* Corresponding author
\end{abstract}

Published: 17 July 2005

Virology Journal 2005, 2:56 doi:10.1 186/1743-422X-2-56

This article is available from: http://www.virologyj.com/content/2///56

(c) 2005 Halford et al; licensee BioMed Central Ltd.

This is an Open Access article distributed under the terms of the Creative Commons Attribution License (http://creativecommons.org/licenses/by/2.0), which permits unrestricted use, distribution, and reproduction in any medium, provided the original work is properly cited.

\begin{abstract}
Background: Interferon- $\gamma$ acts to multiply the potency with which innate interferons $(\alpha / \beta)$ suppress herpes simplex virus type I (HSV-I) replication. Recent evidence suggests that this interaction is functionally relevant in host defense against HSV-I. However, it is not clear which WBCs of the innate immune system, if any, limit HSV-I spread in an IFN- $\gamma$ dependent manner. The current study was initiated to determine if natural killer (NK) cells provide innate resistance to HSV-I infection, and if so to determine if this resistance is IFN- $\gamma$-dependent.

Results: Lymphocyte-deficient scid or rag2-- mice were used to test four predictions of the central hypothesis, and thus determine if innate resistance to HSV-I is dependent on I. NK cell cytotoxicity, 2. NK cells, 3. WBCs, or 4. the IFN-activated transcription factor, Stat I. Loss of NK cell cytotoxic function or depletion of NK cells had no effect on the progression of HSV-I infection in scid mice. In contrast, viral spread and pathogenesis developed much more rapidly in scid mice depleted of WBCs. Likewise, loss of Stat I function profoundly impaired the innate resistance of rag2-/- mice to HSV-I.
\end{abstract}

Conclusion: Lymphocyte-deficient mice possess a very tangible innate resistance to HSV-I infection, but this resistance is not dependent upon NK cells.

\section{Background}

Severe infections with herpesviruses such as herpes simplex virus type 1 (HSV-1) have been observed in natural killer (NK) cell-deficient individuals [1-3]. This observation has fostered the belief that NK cells play a central role in innate resistance to HSV-1 infection. This hypothesis is further supported by the mechanism of action of the viral ICP47 protein. ICP47 binds the cellular antigen transporter, TAP1, and thus prevents MHC class I molecules from being transported to the surface of HSV-1 infected cells [4]. This inhibition of MHC class I transport appears to explain the long recognized fact that HSV-1 infection renders cultured cells vulnerable to NK cell-mediated lysis [5-7]. Indeed, expression of ICP47 is sufficient, in and of itself, to downregulate MHC class I and induce NK cellmediated lysis of human cells [8]. Numerous in vitro and in vivo studies also support the tenet that NK cells play an integral role in innate resistance to HSV-1 infection [913].

Against this background, it is not surprising that most current texts and reviews indicate that NK cells are essential for host resistance to HSV-1 infection [14-18]. However, this tenet is based upon equivocal evidence. A handful of 
animal studies from the last 25 years indicate that NK cells are not essential for host resistance to HSV-1 [19-21]. More recently, a similar conclusion was reached based on the comparison of HSV-1 infection in rag2 $\%$ mice versus rag $2 \% \gamma_{c}^{-/}$mice [22]. However, loss of $\gamma_{c}$ not only prevents NK cell development, but also renders mice null for the function of interleukins (IL)-2,-4,-7,-9,-15, and -21. Given its pleiotropic effects [23-25], the $\gamma_{c}^{-/-}$mutation does not provide a compelling basis for drawing inferences about any one component of the innate immune system. Numerous NK cell studies are confounded by similar caveats. For example, NK cell depletion has been found to impair host resistance to HSV-1 infection $[12,26]$, but activated T cells also express "NK cell" markers [27]. Therefore, the effect of anti-asialo GM1 and anti-NK1.1 antibodies on host resistance to HSV-1 may be due, at least in part, to their capacity to blunt the $\mathrm{T}$ cell response to viral infections [27].

Interferon (IFN)- $\gamma$ multiplies the potency with which the innate IFNs, IFN- $\alpha$ and/or IFN- $\beta$, suppress HSV- 1 replication [28]. This cooperative inhibition by IFN- $\alpha / \beta$ and IFN- $\gamma$ effectively prevents virus-infected cells from synthesizing new HSV-1 virions [29]. The profoundly accelerated rate of HSV-1 spread in receptor-deficient mice suggests that the interaction between the IFN- $\alpha / \beta$-and IFN- $\gamma$-signaling pathways is functionally relevant in innate resistance to HSV-1 [22,30]. Consistent with this hypothesis, IFN- $\gamma$ expression is evident in HSV-1 infected tissues just 24 hours post inoculation (p.i.; Fig. 7 of Ref. [31]). T cells, NK cells, and professional antigen-presenting cells (APCs) are the primary IFN- $\gamma$-producers in the body $[32,33]$. CD $8^{+} \mathrm{T}$ cells play a major role in immune surveillance of HSV-1 latently infected ganglia, and can directly suppress HSV-1 reactivation in neurons in a manner that is MHC class Irestricted and IFN- $\gamma$-dependent [34-38]. However, it is unknown if NK cells and/or professional APCs confer innate resistance to HSV-1 infection via the secretion of IFN- $\gamma$ at early times p.i.

The following study was initiated to determine if NK cells provide innate resistance to HSV-1 infection via their capacity to rapidly deliver IFN- $\gamma$ to sites of viral replication. Scid or rag $2 \%$ mice were used to test four predictions that follow from this central hypothesis. Specifically, experiments were performed to determine if innate resistance to HSV-1 is dependent on 1 . NK cell cytotoxicity, 2. NK cells, 3. WBCs, or 4 . the IFN-activated transcription factor, Stat $1[39,40]$. The use of lymphocyte-deficient mice assured that this analysis of innate resistance was not confounded by the dominant effects of the adaptive immune response. The results demonstrate that although scid and rag $2 \%$ mice possess a measurable resistance to HSV-1, this innate resistance is not dependent upon NK cells.

\section{Results}

\section{Immune status of $B A L B / c$ scid mice}

Lymphocyte maturation is not completely blocked in some strains of scid mice [41-43]. Thus, B and T lymphocyte function were evaluated in scid mice. Assessment of B cell function indicated that BALB/C mice had serum IgG levels of $6.4 \pm 1.3 \mathrm{mg} / \mathrm{ml}$, whereas serum IgG was undetectable in scid mice (Fig. 1A). Flow cytometric analysis indicated that BALB/c mice contained an average 110 million WBCs per spleen, of which $21 \%$ were CD $4^{+} \mathrm{T}$ cells, $10 \%$ were $\mathrm{CD}^{+} \mathrm{T}$ cells, and $2.5 \%$ were $\mathrm{CD} 3$ CD $49 \mathrm{~b}^{+} \mathrm{NK}$ cells (Fig. 1B). In contrast, scid mice contained an average 8 million WBCs per spleen, of which $<0.1 \%$ were $\mathrm{CD}^{+}{ }^{+}$or $\mathrm{CD}^{+} \mathrm{T}$ cells and $45 \%$ were $\mathrm{CD} 3-$ CD49b+ NK cells (Fig. 1B).

Adoptive transfer was performed to verify that adaptive resistance to HSV-1 could be restored to scid mice. Following ocular inoculation with HSV-1 strain KOS, scid mice shed high titers of virus between 1 and 7 days p.i. (Fig. 1C). On day 7 p.i., scid mice were i.v. administered either a. vehicle, b. total WBCs, c. purified B cells, or d. purified $\mathrm{T}$ cells from naïve BALB/c donors (Fig. 1C). Vehicletreated scid mice continued to shed high levels of virus (Fig. 1C) and succumbed to the infection within $17 \pm 2$ days p.i. (Fig. 1D). Scid mice reconstituted with total WBCs shed 30-fold less virus than vehicle-treated controls on day 14 p.i. (Fig. 1C) and 8 of 8 survived the infection (Fig. 1D). Scid mice reconstituted with purified B cells eventually died, but the mean time of survival was increased to $22 \pm 3$ days (Fig. 1D). Reconstitution with purified T cells controlled HSV-1 infection in 8 of 8 scid mice, but viral shedding continued for $\sim 3$ days longer than scid mice reconstituted with total WBCs (Fig. 1C). Thus, all measures indicated that scid mice are effectively devoid of B and T lymphocyte function.

\section{Innate resistance to HSV-I is not dependent on NK cell cytotoxicity}

To determine if innate resistance to HSV-1 is dependent on NK cell cytotoxic function, infection with HSV-1 strain KOS was compared in BALB/c scid mice versus non-obese diabetic (NOD) scid mice. Consistent with previous reports $[44,45]$, WBCs isolated from the spleens of NOD scid mice were functionally deficient in NK cell cytotoxic activity relative to BALB/c mice and BALB/c scid mice (Fig. $2 \mathrm{~A})$. Following ocular inoculation with $2 \times 10^{5} \mathrm{pfu} /$ eye, HSV-1 strain KOS replicated to high and equivalent titers in BALB/c scid mice and NOD scid mice between 1 and 14 days p.i. (not shown). No differences were observed in the progression of viral pathogenesis or the duration of survival of BALB/c scid mice versus NOD scid mice (Fig. 2B). Flow cytometry demonstrated that approximately onethird of the peripheral WBCs of NOD scid mice possessed the CD3-CD49b+ phenotype of NK cells (Fig. 2C) $[46,47]$. 
A.
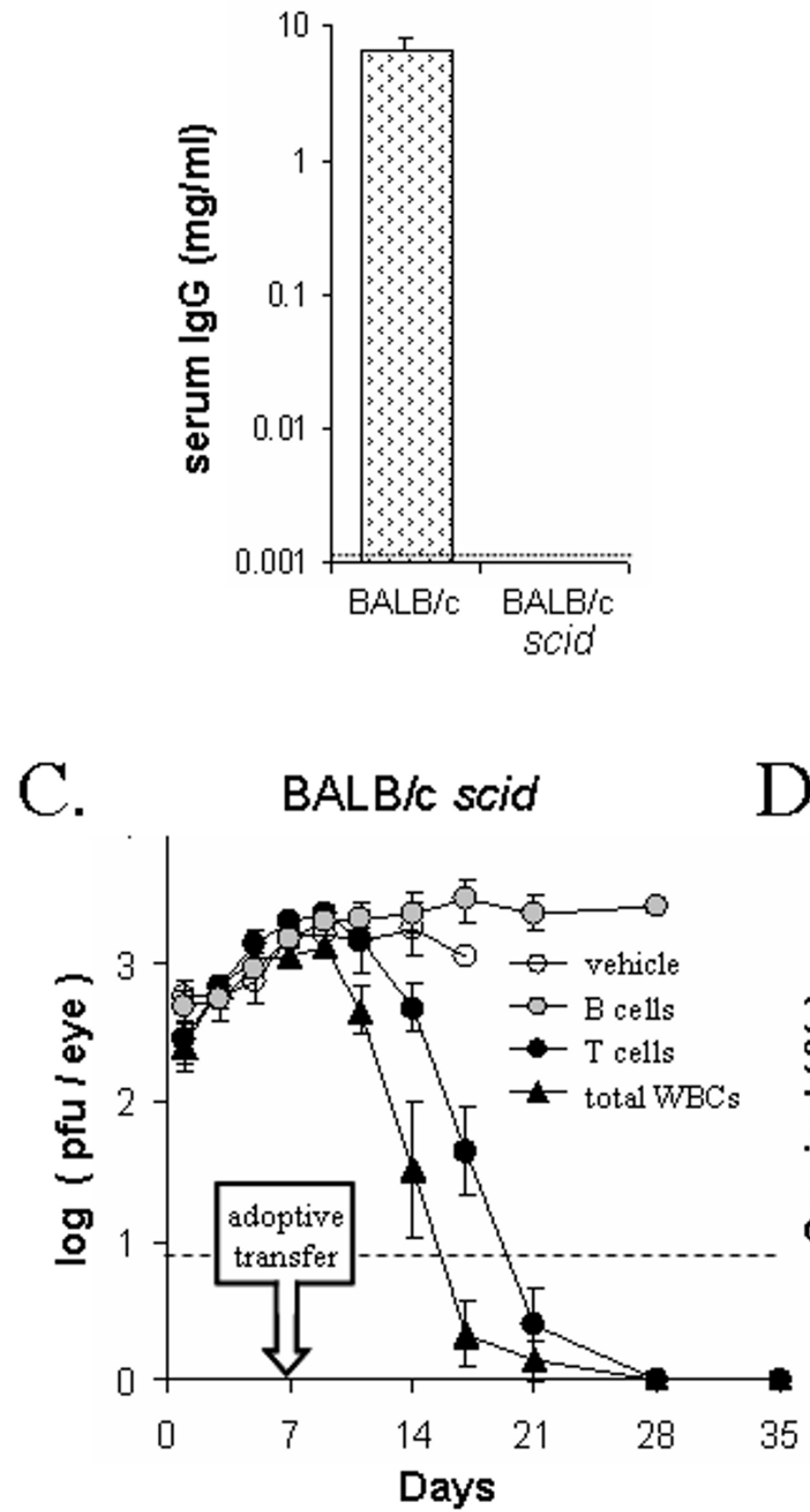

B.
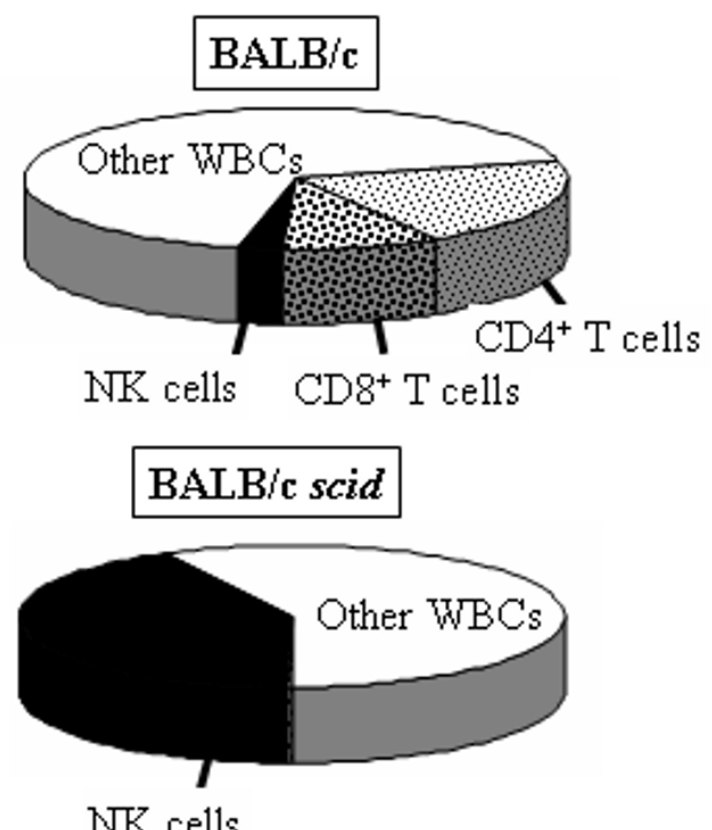

NK cells

Figure I

Immune status of BALB/c scid mice. A. ELISA measurement of serum lgG levels in BALB/c and BALB/c scid mice $(n=5$ per group; dashed line denotes lower limit of detection). B. Flow cytometric measurement of the abundance of $C D 4^{+} T$ cells, CD8 ${ }^{+} \mathrm{T}$ cells, and CD3- CD49b ${ }^{+} \mathrm{NK}$ cells in the spleens of BALB/c versus scid mice $(n=10$ per group). "Other WBCs" refers to the fraction of spleen cells not labeled by antibodies against CD3, CD4, CD8, and CD49b. C and D. Effect of adoptively transferred naïve lymphocytes on scid mouse resistance to HSV-I. C. Viral titers per eye (dashed line denotes lower limit of detection) and $\mathbf{D}$. duration of survival of scid mice inoculated with $2 \times 10^{5}$ pfu/eye HSV-I strain KOS. On day 7 p.i., scid mice (n $=8$ per group) received an i.v. injection of medium (vehicle) or medium containing $5 \times 10^{6} \mathbf{B}$ cells, T cells, or unfractionated WBCs (total WBCs) obtained from naïve BALB/c donors. 

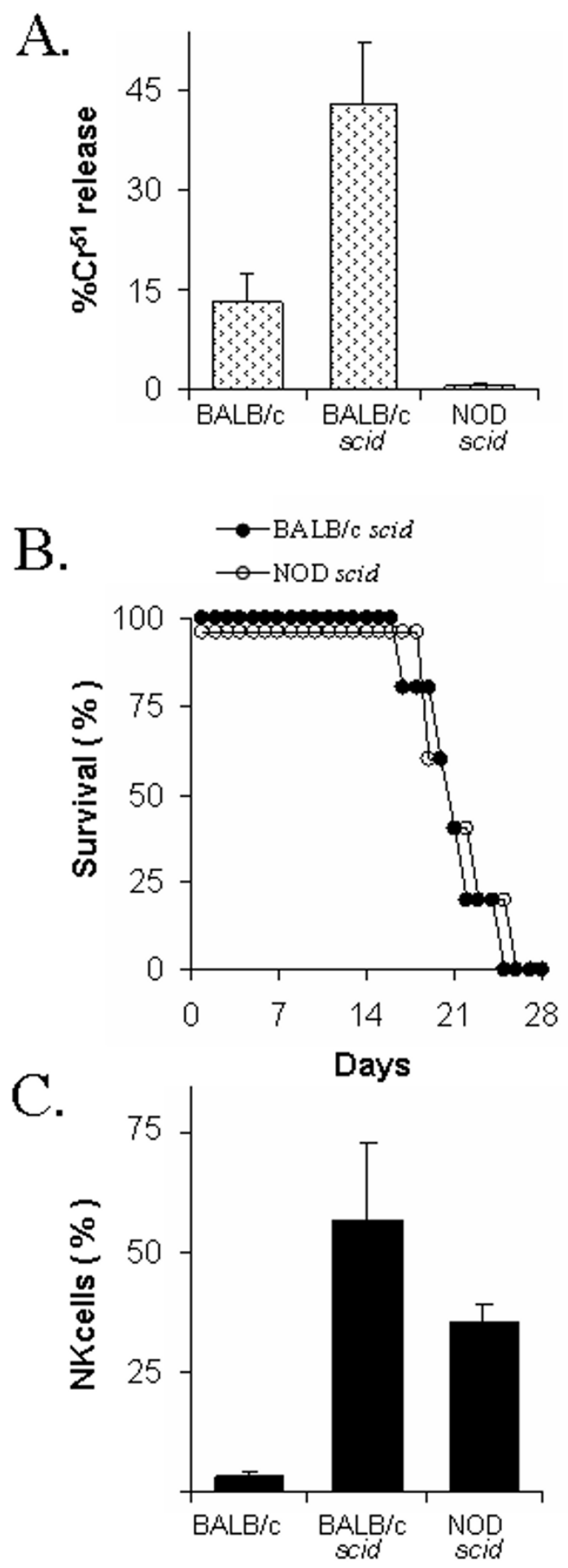

Figure 2

Innate resistance to HSV-I is not dependent on NK cell cytotoxicity. A. Cytotoxic activity of WBCs from BALB/c, $\mathrm{BALB} / \mathrm{c}$ scid, or NOD scid mice, as determined by percent maximum ${ }^{51} \mathrm{Cr}$ release achieved when $10^{4} \mathrm{YAC}-\mathrm{I}$ (target) cells were incubated with 250,000 spleen WBCs ( $n=3$ per group). B. Duration of survival of BALB/c scid mice and NOD scid mice following ocular inoculation with $2 \times 10^{5}$ pfu/eye HSV-I strain KOS ( $\mathrm{n}=5$ per group). $\mathbf{C}$. NK cell frequency in the spleens of $\mathrm{BALB} / \mathrm{c}, \mathrm{BALB} / \mathrm{c}$ scid, or NOD scid mice ( $\mathrm{n}=2$ per group). 


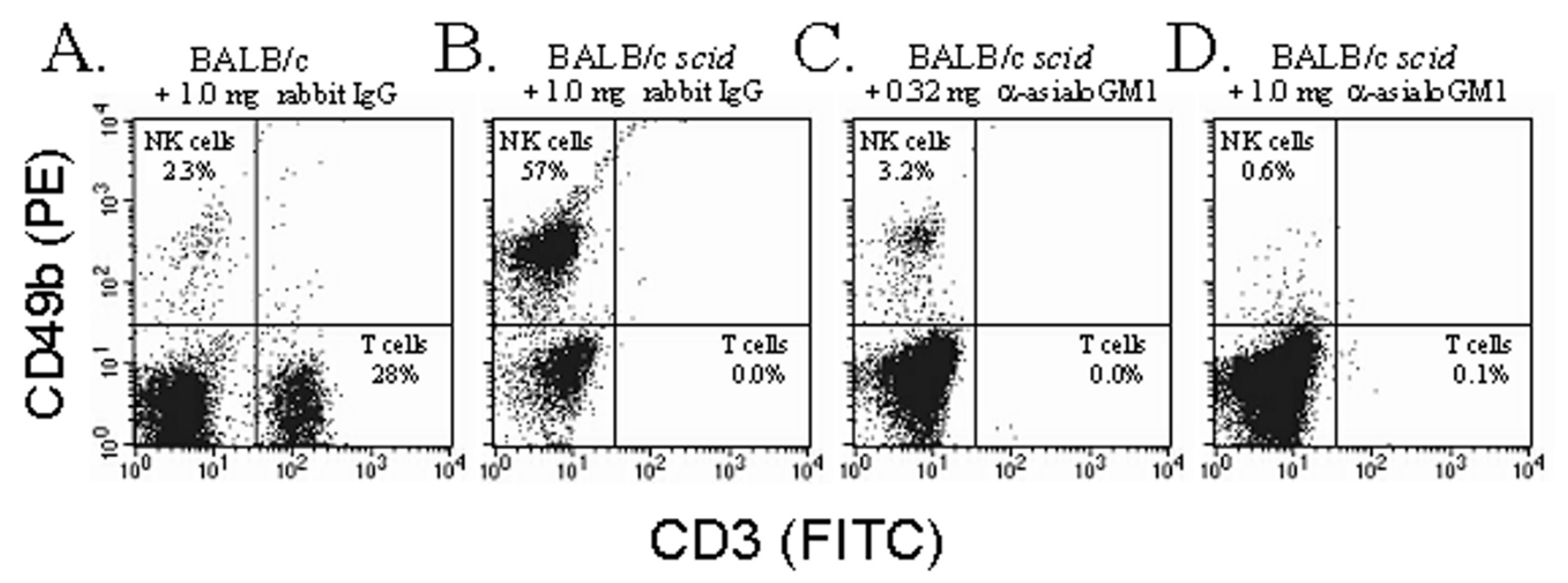

Figure 3

Efficacy of NK cell depletion with anti-asialo GMI antibody. The frequency of CD3- CD49b+ NK cells in the spleens of A. BALB/c mice and B. BALB/c scid mice that received i.p. injections of $1.0 \mathrm{mg}$ per day control rabbit lgG, as compared to scid mice treated with C. 0.32 or D. $1.0 \mathrm{mg}$ per day of rabbit anti-asialo GMI. Mice were treated with antibody on Days 0 and 3 , and spleen WBCs were isolated on Day 4 for flow cytometric analysis with FITC-labeled anti-CD3 and PE-labeled anti-CD49b. The frequency of NK cells (upper left quadrant) and $\mathrm{CD}^{+} \mathrm{T}$ cells are indicated on each graph. Results are representative of three independent experiments.

Thus, despite the lack of in vitro cytotoxic activity (Fig. 2A), NOD scid mice still possessed significant numbers of NK cells that could control HSV-1 infection via other mechanisms (e.g., IFN- $\gamma$ secretion).

\section{Innate resistance to HSV-I is not dependent on NK cells}

Preliminary experiments indicated that two treatments with 0.32 or $1.0 \mathrm{mg}$ rabbit anti-asialo GM1 reduced the number of NK cells in BALB/c scid mouse spleens by $>10$ and $>50$-fold, respectively, whereas control rabbit IgG produced no such effect (Fig. 3). Thus, anti-asialo GM1 antibody was used to determine if NK cells are necessary for innate resistance to HSV-1.

BALB/c mice and BALB/c scid mice were treated with PBS, control IgG, or anti-asialo GM1 and were inoculated with $2 \times 10^{5} \mathrm{pfu} /$ eye of HSV-1 strain KOS. In BALB/c mice, KOS replicated to similar viral titers in mice treated with PBS, control rabbit IgG, or anti-asialo GM1, with one notable exception (Fig. 4A). On days 5 and 7 p.i., BALB/c mice treated with rabbit anti-asialo GM1 shed $\sim 5$-fold more virus than PBS-treated controls (Fig. 4A; $\mathrm{p}<0.05$, denoted by asterisks). Between days 9 and 14 p.i., viral shedding was detected in none of the BALB/c mice (Fig. 4A). Likewise, viral pathogenesis was limited, and $100 \%$ of BALB/C mice survived infection with HSV-1 strain KOS (Fig. 4B).
BALB/c scid mice shed infectious KOS continuously during the 14-day sampling period (Fig. 4A). Treatment with rabbit anti-asialo GM1 had no effect on the titers of infectious KOS recovered from the eyes of BALB/c scid mice between 1 and 14 days p.i. (Fig. 4A). Scid mice treated with PBS survived for $16 \pm 1$ days p.i. (Fig. 4B). Treatment with rabbit anti-asialo GM1 did not shorten the duration of survival of KOS-infected scid mice (Fig. 4B). Paradoxically, treatment with rabbit anti-asialo GM1 or control rabbit IgG increased the duration of survival of KOSinfected BALB/c scid mice to $24 \pm 1$ and $35 \pm 3$ days p.i., respectively (Fig. 4B; p <0.001). Multiple experiments confirmed this unexpected effect that rabbit immunoglobulin (with no reactivity against HSV-1) prolonged the survival of KOS-infected scid mice. The interpretation of these data was complicated by this caveat. However, it was clear that NK cell depletion did not fundamentally alter the progression of HSV-1 infection in scid mice during the first week p.i.

Innate resistance to KOS is dependent on peripheral WBCs Cyclophosphamide (CyP) is an alkylating agent that is rapidly converted in vivo into metabolites that cause lethal DNA damage in dividing cells [48,49], and transiently reduce peripheral WBC counts by $\sim 90 \%$ in mice [31]. To determine if WBCs are necessary for innate resistance to HSV-1, BALB/c mice and scid mice were treated with PBS 


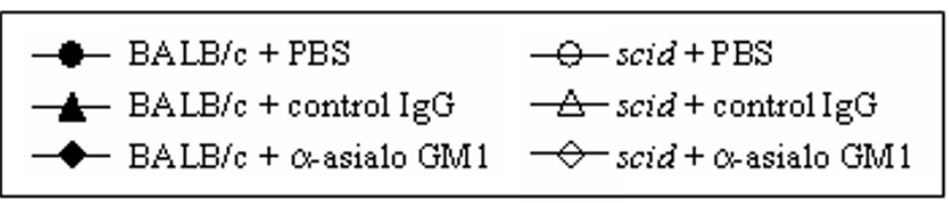

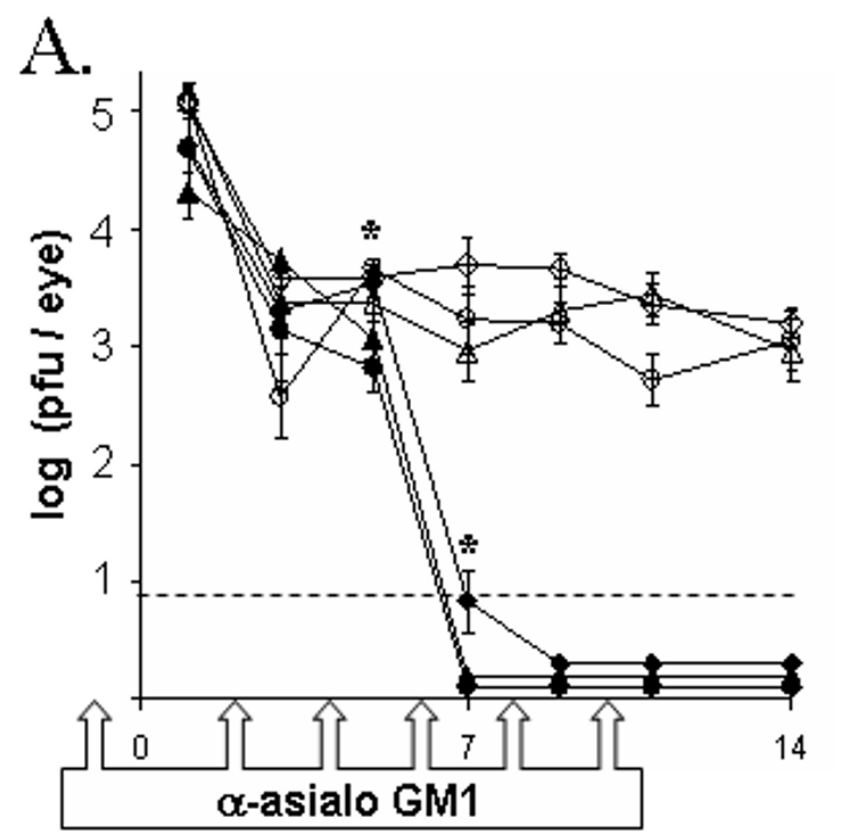

Days

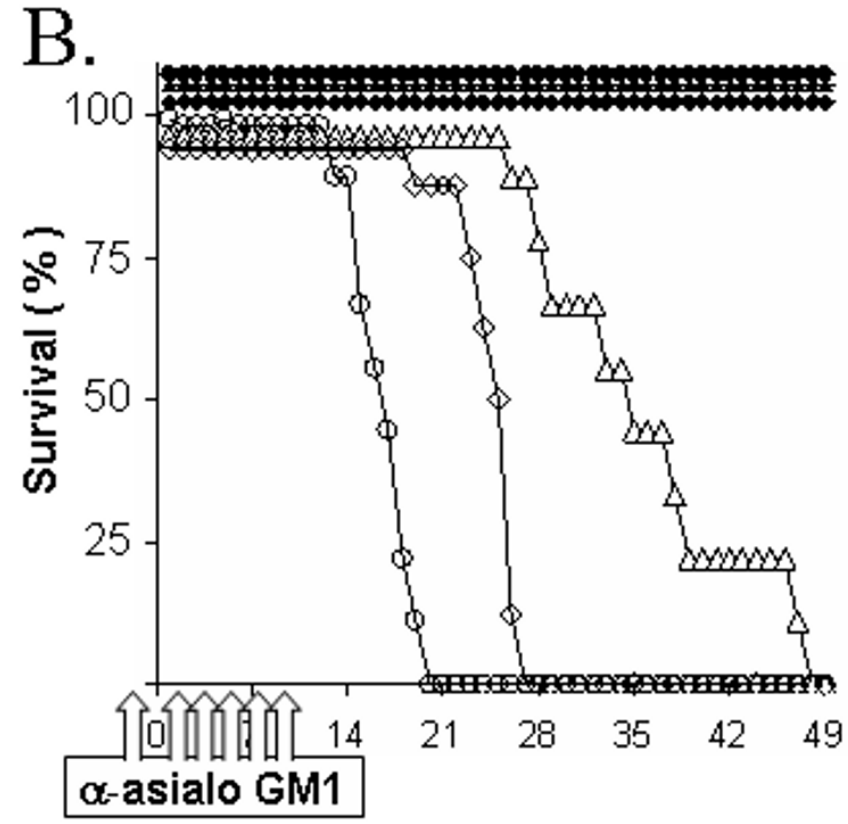

Days

\section{Figure 4}

Effect of NK cell depletion on innate resistance to HSV-I. BALB/c mice and BALB/c scid mice, inoculated with $2 \times 10^{5}$ pfu/eye HSV-I strain KOS, received i.p. injections of PBS, control IgG or anti-asialo GMI (I.2 mg) on days -I, 2, 4, 6, 8 and I0 p.i. A. Viral replication in the eyes of BALB/c mice and scid mice treated with PBS, control IgG or anti-asialo GMI (mean \pm SEM; $n$ = 9; dashed line denotes lower limit of detection). Asterisks denote times at which anti-asialo GMI-treated BALB/c mice shed more virus than PBS-treated BALB/c mice $(p<0.05$, ANOVA and Tukey's post hoc t-test). B. Duration of survival of HSV-I infected BALB/c mice and scid mice treated with PBS, control IgG or anti-asialo GM ( $n=9$ per group).

or CyP and were inoculated with $2 \times 10^{5}$ pfu/eye of HSV1 strain KOS. On day 4 p.i., peripheral WBC counts (WBCs per $\mathrm{ml} \times 10^{6}$ ) in each group were, as follows: $\mathrm{BALB} / \mathrm{c}+\mathrm{PBS}=6.6 \pm 0.5 ;$ scid $+\mathrm{PBS}=2.3 \pm 0.2 ; \mathrm{BALB} / \mathrm{c}+$ $\mathrm{CyP}=0.8 \pm 0.1 ;$ and scid $+\mathrm{CyP}=0.4 \pm 0.1$. Similar viral titers were recovered from the eyes of all mice at 24 hours p.i. (Fig. 5A). However, BALB/c mice treated with $\mathrm{CyP}$ shed 30- to 1000-fold more virus than PBS-treated BALB/ c mice between 5 and 9 days p.i. (Fig. 5A; p $<0.05$, denoted by asterisks). Likewise, CyP-treated scid mice shed 2- to 7-fold more virus than PBS-treated scid mice between 5 and 9 days p.i. (Fig. 5A). Viral titers were not determined in CyP-treated mice on 11 and 14 days p.i. because the extent of ocular pathogenesis precluded a reliable measurement.

BALB/c mice treated with PBS uniformly survived ocular HSV-1 infection (Fig. 5B). In contrast, 0\% of CyP-treated $\mathrm{BALB} / \mathrm{C}$ mice survived HSV-1 infection (Fig. 5B). The death of these mice was not a direct consequence of CyP's toxicity, because $100 \%$ of uninfected BALB/c controls survived the same course of CyP treatment (Fig. 5B). PBStreated scid mice survived ocular inoculation with HSV-1 strain KOS for $18 \pm 1$ days (Fig. 5C). In contrast, CyPtreated scid mice succumbed to HSV-1 infection within 12 \pm 1 days (Fig. 5C; $\mathrm{p}<0.001$ ). This reduced duration of survival was not a direct consequence of CyP's toxicity, 


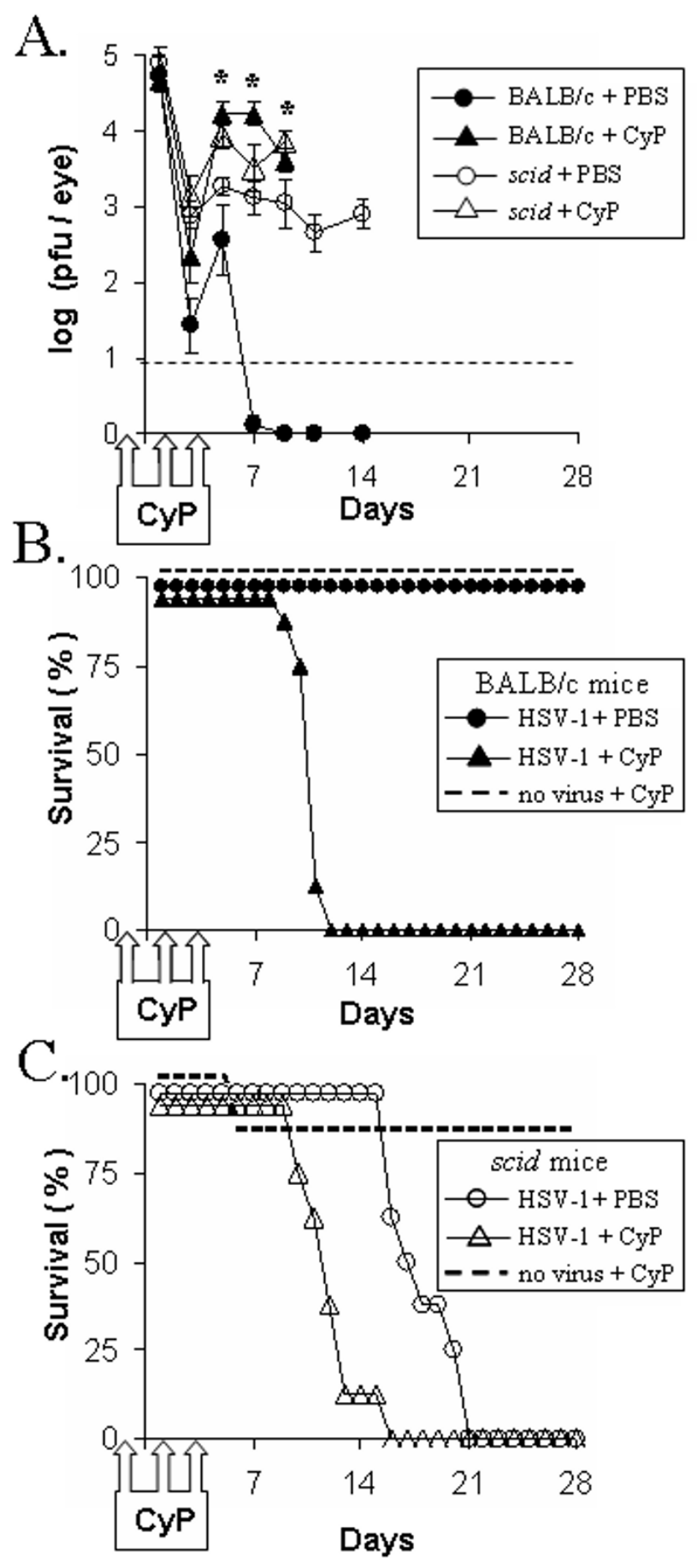

Figure 5

Effect of WBC depletion on innate resistance to HSV-I. BALB/c mice and BALB/c scid mice, inoculated with $2 \times 10^{5}$ pfu/eye HSV-I strain KOS, received i.p. injections of PBS or cyclophosphamide (CyP; I $25 \mathrm{mg} / \mathrm{kg}$ ) on days $-\mathrm{I}$, I, and 3 p.i. Uninfected BALB/c mice and uninfected scid mice received i.p. injections of CyP at the same time points $(n=8$ per group). A. Viral replication in the eyes of BALB/c mice and scid mice treated with PBS or CyP (mean \pm SEM; $n=8$; dashed line denotes lower limit of detection). Asterisks denote times at which CyP-treated BALB/c mice shed more virus than PBS-treated BALB/c mice $(p<0.05$, ANOVA and Tukey's post hoc t-test). B and C. Duration of survival of HSV-I infected B. BALB/c mice and C. scid mice treated with PBS or CyP versus uninfected, CyP-treated controls ( $n=8$ per group). 
Table I: Duration of survival of HSV-I infected scid mice.

\begin{tabular}{|c|c|c|c|c|c|}
\hline \multirow[b]{2}{*}{ Expt. } & \multirow[b]{2}{*}{ Virus } & \multicolumn{4}{|c|}{ Treatment $^{\mathrm{a}}$} \\
\hline & & PBS & rabbit IgG & NK-depleted ${ }^{\mathrm{b}}$ & WBC-depleted ${ }^{\mathrm{C}}$ \\
\hline $\mathrm{Id}^{2}$ & KOS & $15.8 \pm 0.8(n=9)^{f}$ & $34.9 \pm 2.8(n=9)$ & $23.5 \pm 0.9(n=9)$ & ND $\mathrm{g}$ \\
\hline 2 & KOS-GFP & $19.0 \pm 0.9(n=5)$ & $36.8 \pm 3.8(n=5)$ & $35.0 \pm 0.6(n=5)$ & ND \\
\hline 3 e & KOS & $18.1 \pm 0.8(n=8)$ & ND & ND & $12.1 \pm 0.7(n=8)$ \\
\hline 4 & KOS-GFP & $23.7 \pm 1.8(n=6)$ & ND & ND & $14.0 \pm 0.6(n=5)$ \\
\hline \multicolumn{2}{|c|}{ Summary } & $19.2 \pm 1.7(n=28)$ & $35.9 \pm 1.3(n=14)$ & $29.3 \pm 5.8(n=14)$ & $13.1 \pm 0.9(n=15)$ \\
\hline
\end{tabular}

a BALB/c scid mice were treated with PBS, control rabbit IgG, rabbit anti-asialo GMI, or cyclophosphamide (CyP) as described in Materials and Methods.

b BALB/c scid mice were treated with rabbit anti-asialo GMI.

c BALB/c scid mice were treated with cyclophosphamide.

$\mathrm{d}$ The results of Experiment $\mathrm{I}$ are presented in Figure 4.

e The results of Experiment 3 are presented in Figure 5.

$\mathrm{f}$ Mean \pm SEM days of survival after ocular HSV-I inoculation of scid mice ( $\mathrm{n}=$ number of mice per treatment).

$g$ Not determined in this experiment.

because 7 of 8 uninfected scid mice survived CyP treatment (Fig. 5C). Therefore, depletion of total WBCs in scid mice was correlated with decreased innate resistance to HSV-1 infection.

\section{Effect of NK cell versus WBC depletion on innate resistance to HSV-I}

The innate resistance of scid mice to HSV-1 infection was not adversely affected by NK cell depletion, but was impaired by CyP-induced depletion of total WBCs (Table I). To assure that inter-experimental variance was not the source of these differences, the effect of NK cell versus total WBC depletion was directly compared in scid mice infected with KOS-GFP, a GFP-expressing recombinant virus [50]. Scid mice were treated with PBS, rabbit IgG, anti-asialo GM1, or CyP and were inoculated with $2 \times 10^{5}$ pfu/eye HSV-1 strain KOS-GFP. GFP expression provided a measure of the extent of KOS-GFP spread in scid mice (Fig. 6A). Anti-asialo GM1 antibody treatment caused a $>20$-fold reduction in NK cell abundance, as determined in $\mathrm{n}=2$ KOS-GFP-infected scid mice sacrificed on day $5 \mathrm{p}$. $\mathrm{i}$ Despite effective depletion of NK cells, neither treatment with control rabbit IgG nor anti-asialo GM1 had a measurable effect on KOS-GFP spread in the eyes or periocular skin of scid mice during the first 6 days p.i. (Fig. 6A). In contrast, CyP treatment enhanced the spread of KOS-GFP into the periocular skin of scid mice on day 6 p.i. relative to the other treatment groups (Fig. 6A).

PBS-treated scid mice infected with HSV-1 strain KOS-GFP survived for $22 \pm 1$ days p.i. (Fig. 6B). NK cell depletion with anti-asialo GM1 did not decrease the duration of survival of HSV-1 infected scid mice (Fig. 6B). Rather, treatment with control IgG or anti-asialo GM1 increased the duration of survival of KOS-GFP infected scid mice (Fig. 6B; $38 \pm 3$ and $35 \pm 2$ days p.i, respectively). In contrast, treatment with CyP significantly reduced the duration of survival of HSV-1-infected scid mice (Fig. 6B; p < $0.001 ; 14 \pm 0.2$ days p.i.). The reduced duration of survival was not due to CyP's toxicity, because 7 of 7 uninfected scid mice survived CyP treatment (Fig. 6B). Thus, while depletion of total WBCs was correlated with decreased innate resistance to HSV-1 infection, depletion of NK cells had no such effect.

\section{Innate resistance to HSV-I infection is dependent on Stat I}

Stat 1 is an IFN-activated transcription factor that is essential for the intracellular response of cells to the cytokines IFN- $\alpha / \beta$ and IFN- $\gamma[39,40]$. Lymphocyte-deficient rag $2 \%$ mice, which were genetically stat $1^{+/+}$versus stat $1^{\%}$, were inoculated with $2 \times 10^{5} \mathrm{pfu} /$ eye HSV-1 strain KOS-GFP. As controls, wild-type strain 129 and stat $1 \%$ mice were also inoculated with KOS-GFP. At 24 hours p.i., GFP expression (Fig. 7A) and infectious KOS-GFP (Fig. 7B) were detected in the eyes of all mice. Between 48 and 96 hours p.i., GFP-expression steadily decreased in the eyes of strain 129 mice and rag2 $\%$ mice infected with KOS-GFP (Fig. $7 \mathrm{~A})$. In contrast, GFP expression continued to spread in the eyes of stat $1 \%$ mice and rag2 $\%$-stat $1 \%$ mice such that 25 to $50 \%$ of the ocular surface was GFP-positive by 72 hours p.i. (Fig. 7A). Likewise, stat $1 \%$ and rag2 $\%$ stat $1 \%$ mice shed 300-fold more virus on day 3 p.i. than wild-type or rag21- mice (Fig. 7B). This rapid response at the site of inoculation was not lymphocyte-dependent, because wild-type mice and rag2 $\%$ mice shed equivalent, low titers of KOSGFP on day 3 p.i. (Fig. 7B). Viral titers were not determined in stat $1 \%$ mice or rag2 $\%$ stat $1 \%$ mice on day 7 p.i. 


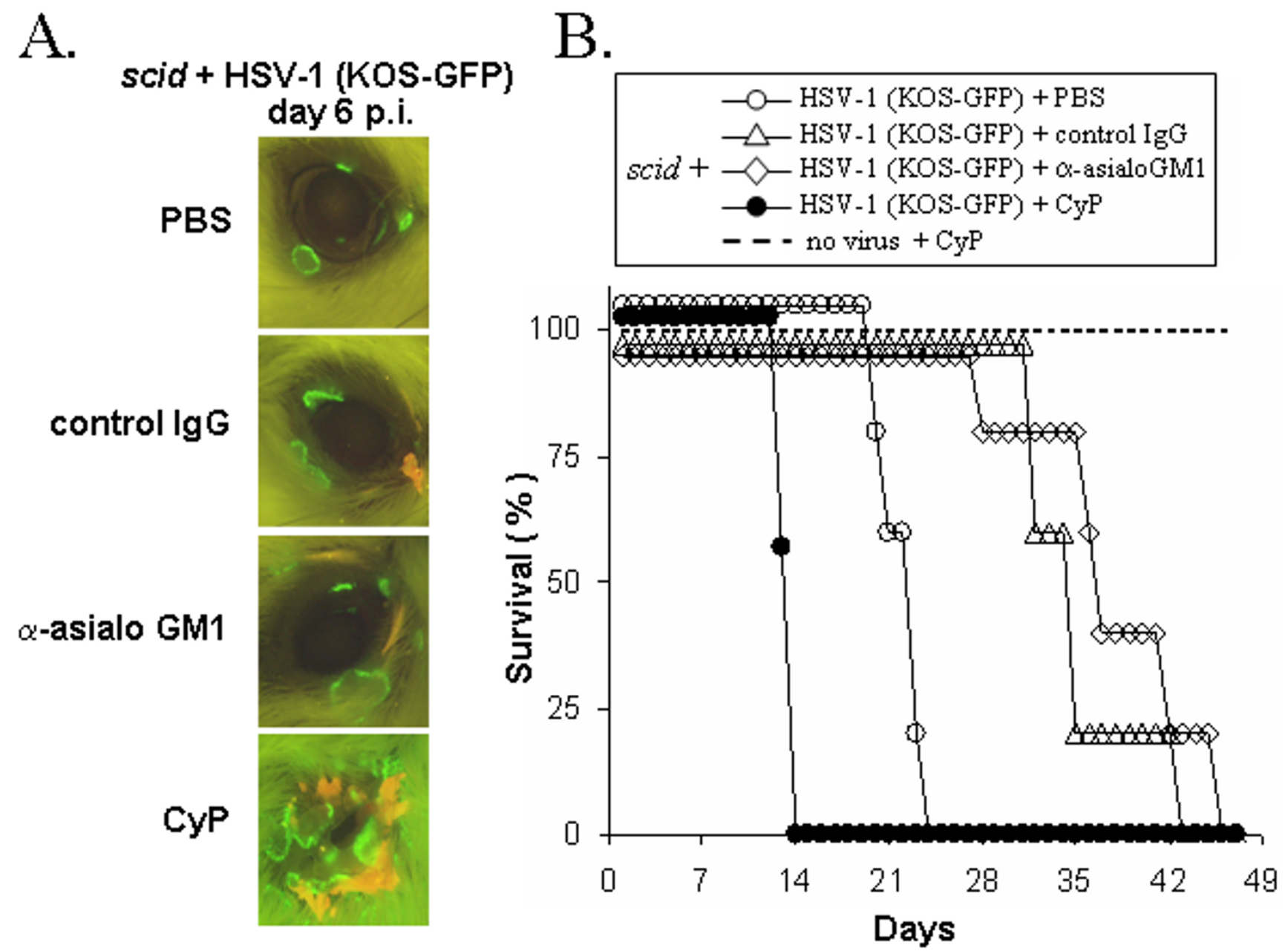

\section{Figure 6}

Effect of NK cell versus WBC depletion on innate resistance to HSV-I. BALB/c scid mice, inoculated with $2 \times 10^{5}$ pfu/ eye HSV-I strain KOS-GFP, received i.p. injections of PBS, control IgG or anti-asialo GMI (I.7 mg) on days -I, 2, 5 and 9 p.i. Cyclophosphamide (CyP; I $25 \mathrm{mg} / \mathrm{kg}$ ) was administered on days -I, I, and 3 p.i. A. Eyes of KOS-GFP-infected scid mice on day 6 p.i (2× magnification, illuminated with 360-400 nm light which excites GFP fluorescence). One representative image was chosen per group. B. Duration of survival of HSV-I infected scid mice treated with PBS or CyP ( $\mathrm{n}=7$ each) or control IgG or antiasialo GMI ( $n=5$ each), as compared to uninfected, CyP-treated scid mice $(n=7)$. Control lgG and anti-asialo GMI treatment groups initially contained $n=7$ mice, but two mice per group were sacrificed on day 5 p.i. for flow cytometry to determine the efficacy of NK cell depletion.

because the extent of ocular pathogenesis precluded a reliable measurement.

Strain 129 (wild-type) mice uniformly survived KOS-GFP infection (Fig. 7C). In contrast, $0 \%$ of rag $\%$ mice survived and their duration of survival was $25 \pm 2$ days p.i. Thus, the duration of survival of KOS-GFP-infected rag2 $\%$ mice was similar to KOS-GFP-infected scid mice (i.e., $21 \pm 3$ days; Table I). Rag $2 \%$ stat $1 \%$ mice succumbed to HSV-1 infection much more rapidly than rag $2 \%$ mice, and survived for only $7.8 \pm 0.4$ days after inoculation with KOS-
GFP (Fig. 7C). Likewise, stat $1 \%$ mice also succumbed to HSV- 1 by $7.8 \pm 0.8$ days p.i., presumably because the viral infection overwhelmed these mice before an adaptive immune response could be mounted. Collectively, the results indicate that innate resistance to HSV-1 infection is intimately dependent on Stat 1-induced gene expression.

\section{Discussion}

The current study was initiated to determine if innate resistance to HSV-1 is dependent on NK cells and their capacity to deliver IFN- $\gamma$ to sites of viral infection. Despite 

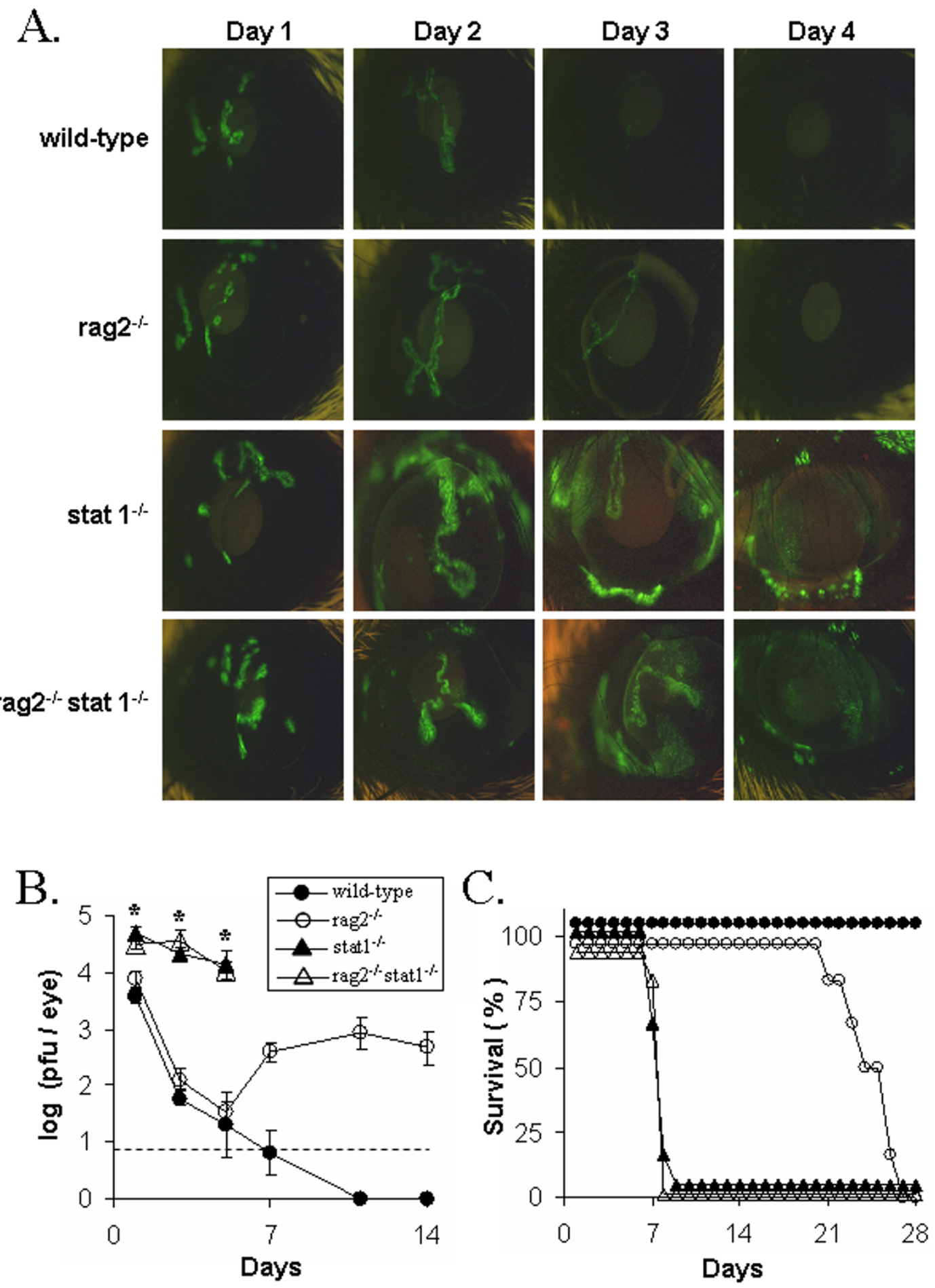

Figure 7

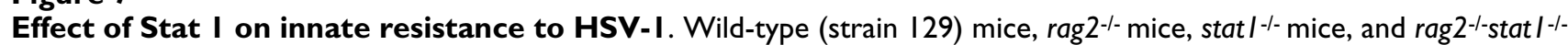
mice were inoculated with $2 \times 10^{5}$ pfu/eye of HSV-I strain KOS-GFP. A. Eyes of KOS-GFP-infected mice on days I, 2, 3, and 4 p.i (4× magnification, illuminated with 360-400 nm light which excites GFP). A representative mouse from each group was sequentially imaged on days I through 4 p.i. B. Replication of HSV-I strain KOS-GFP in the eyes of mice (mean \pm SEM; $n=6$; dashed line denotes lower limit of detection). Asterisks denote times at which stat $I^{-/-}$mice shed more virus than stat $I^{+/+}$mice $(p<0.05$, ANOVA and Tukey's post hoc t-test). C. Duration of survival of HSV-I infected mice ( $n=6$ per group). 
the fact that $45 \%$ of peripheral WBCs in scid mice are NK cells (i.e., CD3-CD49b+; Ref. $[46,47])$, NK cells made no measurable contribution to innate resistance to HSV-1. Thus, the focus of this study rapidly shifted away from the effector mechanisms that NK cells use to control HSV-1 infection, and shifted towards a series of experiments to validate that lymphocyte-deficient mice indeed possess a measurable innate resistance to HSV-1. The results are discussed, as follows.

\section{Role of NK cells in innate resistance to HSV-I}

Despite a large differential in NK cell cytotoxicity, NOD scid mice possessed an innate resistance to HSV-1 infection that was equivalent to BALB/C scid mice. One interpretation of the results is that NK cell function is not essential for innate resistance to HSV-1. However, the fact that peripheral WBCs of NOD scid mice lack detectable NK cell cytotoxic activity in vitro does not prove that NOD scid mice are devoid of NK cell function in vivo. Indeed, one-third of peripheral WBCs in NOD scid mice were found to be CD3-CD49b+NK cells. Thus, we were hesitant to use the behavior of HSV-1 in NOD scid mice as the basis for concluding that NK cells play no role in innate resistance to HSV-1. Likewise, we question the validity of comparisons of HSV-1 infection in mice that exhibit "high" or "low" natural cytotoxicity in vitro, because there is no evidence that these mice lack NK cell function in vivo $[21,51]$.

$\mathrm{T}$ cells that become activated in response to viral infections express the "NK cell" markers asialo GM1, NK1.1, and CD49b (i.e., antigen recognized by DX5 monoclonal antibody; Ref. [47]). Thus, depletion of asialo GM1+ T cells or NK1.1+ T cells may account for the capacity of antiasialo GM1 or anti-NK1.1 to impair the resistance of $\mathrm{BALB} / \mathrm{C}$ and C57BL/ 6 mice to HSV-1 infection $[12,26,27]$. Consistent with this hypothesis, anti-asialo GM1 increased ocular viral titers in BALB/c mice on days 5 and 7 p.i., but produced no such effect in scid mice (Fig. 4). In $\mathrm{BALB} / \mathrm{c}$ scid mice, NK cell depletion had no effect on (a) ocular viral titers or (b) the rate of KOS-GFP spread to the periocular skin. An important caveat of the NK cell depletion experiments was that control IgG or anti-asialo GM1 had the unanticipated effect of prolonging the survival of HSV-1 infected scid mice. Neither IgG preparation possessed neutralizing activity or reactivity with HSV-1 antigens by ELISA. This effect raises questions about the homeostatic mechanisms and Fc- $\gamma$-receptor dependent processes that are influenced when IgG is introduced into a scid mouse for the first time in its life [52-55]. However, the relevant point for this study is that a $>95 \%$ reduction in NK cell abundance does not impair the capacity of a scid mouse to limit HSV-1 spread from the site of inoculation.

\section{Role of peripheral WBCs in innate resistance to HSV-I}

The lack of effect of NK cell depletion on innate resistance to HSV-1 is only relevant if scid mice possess a measurable innate resistance to HSV-1. CyP-induced depletion of total WBCs in scid mice was associated with 1 . increased HSV-1 spread from the site of inoculation (evident by day 6 p.i.) and a 2. reduced duration of survival. CyP impairs the immune response of normal mice to HSV-1 [31]. This study provides the first evidence that $\mathrm{CyP}$ can also be used to blunt the innate immune response to HSV-1. CyP has a narrow therapeutic window; there is only a 4 -fold difference between the minimum effective dose and a fatal dose. Thus, we suspect that antibody-based depletion of the relevant WBC effector(s) would cause a more profound decrease in innate resistance to HSV-1. Based on recent evidence, professional APCs such as dendritic cells may be the relevant cellular targets whose depletion accounts for CyP's capacity to impair innate resistance to HSV-1 [56,57]. Further study is needed to test this hypothesis.

\section{Role of Stat I in innate resistance to HSV-I}

The biological functions of IFN- $\alpha / \beta$ and IFN- $\gamma$ are dependent on the phosphorylation of Stat 1, which results in Stat 1 dimerization, nuclear translocation, and transcriptional activation of IFN-stimulated genes [39,58]. HSV-1 infection was compared in rag $2 \%$ mice versus rag $2 \%$ stat $1 \%$ mice to determine if innate resistance to HSV-1 is dependent on Stat 1-induced gene expression. Profound differences in viral titers and viral spread were evident in stat1\%-versus stat $1^{+/+}$mice by 3 days p.i. The rapidity with which HSV-1 infection spread in the absence of Stat 1 (i.e., a relevant effector) underscored the remarkable lack of effect that NK cell depletion had on innate resistance to HSV-1. The defect in Stat 1 rendered rag2 $\%$ stat $1 \%$ mice incapable of limiting HSV-1 spread, and these mice succumbed to the viral infection just $7.8 \pm 1$ days p.i. In contrast, the weakly virulent KOS-GFP strain [50] caused a slowly progressing infection in rag $2 \%$ mice that was not lethal until $25 \pm 2$ days p.i. Thus, Stat 1 plays an integral role in innate resistance to HSV-1 infection. Likewise, a similar phenotype of uncontrolled HSV-1 spread has been observed in IFN- $\alpha$ / $\beta \mathrm{R}^{-/-}$IFN- $\gamma \mathrm{R}^{-/-}$double knockout mice $[22,30]$. Thus, the available evidence suggests that IFN $\alpha / \beta$ and IFN- $\gamma$ are important activators of Stat 1-induced resistance to HSV-1 in vivo. However, further studies are necessary to determine if chemokines and pro-inflammatory cytokines are also important contributors to Stat 1-dependent innate resistance to HSV-1.

\section{Conclusion}

It has become evident that host IFNs are essential mediators of innate resistance to HSV-1 infection. Co-activation of IFN- $\alpha / \beta$ and IFN- $\gamma$ signaling pathways produces a cooperative inhibition that renders host cells highly resistant to 
the replication of herpesviruses [59-62]. In the case of HSV-1, IFN- $\gamma$ achieves this effect by multiplying the potency with which IFN- $\alpha / \beta$ inhibits viral replication [28]. The uncontrolled spread of HSV-1 in IFN- $\alpha / \beta \mathrm{R}^{-/}$ IFN- $\gamma \mathrm{R}-$ mice strongly suggests that this interaction is functionally relevant in vivo $[22,30]$. However, it remains to be determined which cells of the innate immune system, if any, are responsible for the rapid delivery and secretion of IFN- $\gamma$ at sites of HSV-1 infection.

Several clinical case reports indicate that NK cells (a major potential source of IFN- $\gamma$ ) are essential for innate defense against HSV-1 infection in humans [1-3]. Yet, NK cells do not make a measurable contribution to the innate resistance of mice to HSV-1. How does one resolve this paradox? One possibility is that the mouse model may grossly underestimate the importance of NK cells in human resistance to HSV-1. The viral ICP47 protein binds human TAP1 with an extraordinarily high-affinity, and thus renders human cells MHC class I-bare and susceptible to NK cell-mediated lysis in vitro $[4,8,63]$. However, ICP47 binds mouse TAP1 with 100-fold lower affinity than human TAP1, and does not efficiently disrupt MHC class I transport in mouse cells [64]. Thus, while NK cells may be integral to the mechanisms by which the human immune system recognizes HSV-infected cells (i.e., MHC class Ibare), the parallel mechanism may simply be non-functional in mice. Therefore, we conclude that while 1 . NK cells are dispensable for the innate resistance of mice to HSV-1 infection, 2. further investigation is necessary to determine what role, if any, NK cells play in human resistance to HSV-1 infection.

\section{Methods}

Viruses, cells, and mice

The wild-type HSV-1 strains KOS [65] and KOS-GFP, a KOS strain engineered to express GFP [50], were generously provided by Dr. Priscilla Schaffer and Dr. John Balliet (Harvard University Medical School, Boston, MA). The viruses were propagated in Vero cells (American Type Culture Collection, Manassas, VA) and stored as viral stocks at $-70^{\circ} \mathrm{C}$ until used. Vero cells were propagated in Dulbecco's modified Eagle medium (DMEM) containing $10 \%$ fetal bovine serum (FBS), hereafter referred to as "complete DMEM." YAC-1 cells (American Type Culture Collection) were propagated in RPMI-1640 containing $10 \%$ FBS.

Female BALB/c, BALB/c scid, and NOD scid mice were obtained from the Jackson Laboratory (Bar Harbor, ME). Female strain 129 mice, rag $2 \%$ mice, stat $1 \%$ mice, and rag $2 \%$ stat $1 \%$ mice were purchased from Taconic Farms (Germantown, NY). These studies were reviewed and approved by an IACUC, and animals were handled in accordance with the NIH Guide for the Care and Use of
Laboratory Animals. Prior to ocular inoculation, mice were anaesthetized by intraperitoneal (i.p.) administration of xylazine $(6.6 \mathrm{mg} / \mathrm{kg})$ and ketamine $(100 \mathrm{mg} / \mathrm{kg})$. Mice were inoculated by scarifying the cornea with the blunted tip of a 25-gauge needle, blotting tear film from the eyes, and by placing $4 \mu \mathrm{l}$ of complete DMEM containing $2 \times 10^{5}$ $\mathrm{pfu} /$ eye of virus on each eye. Viral titers were determined by swabbing the ocular surface of both eyes at times after inoculation with a cotton-tipped applicator. The tip of the applicator was removed, incubated in $0.4 \mathrm{ml}$ complete DMEM for 1 hour on ice, and viral titers were determined in the supernatant by a microtiter plate plaque assay. Following anaesthetization of mice, fluorescent images of mouse eyes infected with HSV-1 strain KOS-GFP were taken at $2 \times$ or $4 \times$ magnification on a Nikon TE300 fluorescent microscope (Nikon Instruments, Lewisville, TX).

\section{Flow cytometric analysis of natural killer cells and T lymphocytes}

Randomly chosen BALB/c, BALB/c scid, and NOD scid mice were tested to confirm that they were deficient for $\mathrm{T}$ and B-cell function. Serum from mice was tested for immunoglobulin G (IgG) levels using an ELISA kit specific for the Fc fragment of mouse IgG (Bethyl Laboratories, Montgomery, TX). Flow cytometric analysis was used to measure the abundance of $\mathrm{CD} 4{ }^{+} \mathrm{T}$ cells and $\mathrm{CD} 8+\mathrm{T}$ cells in the spleens of selected mice, as described below.

Cells were harvested from the spleens of mice and red blood cells were removed by hypotonic lysis in $0.84 \%$ $\mathrm{NH}_{4} \mathrm{Cl}$. WBCs were labeled with fluorescent-labeled monoclonal antibodies obtained from BD Biosciences (San Jose, CA) according to the manufacturer's directions. For each mouse analyzed, $1 \times 10^{6}$ WBCs were labeled with either 1. nothing, 2. fluorescein-isothiocyanate (FITC)labeled anti-CD3 (clone 17A2) + phycoerythrin (PE)labeled anti-CD4 (clone GK1.5), 3. FITC-labeled antiCD3 + PE-labeled anti-CD8 (clone Ly-2), or 4. FITClabeled anti-CD3 + PE-labeled anti-CD49b (clone DX5). Additionally, controls were included for gating and compensation, and these included WBCs labeled with 5. nothing, 6. FITC-labeled $\operatorname{IgG}_{2 \mathrm{~b}}$ isotype control (clone G27-35), 7. PE-labeled $\operatorname{IgG}_{2 \mathrm{~b}}$ isotype control (clone G27-35), 8. PElabeled $\operatorname{IgG}_{2 \mathrm{a}}$ isotype control (clone G155-178), or 9. PElabeled IgM isotype control (G155-258). Flow cytometry was performed immediately after antibody labeling on a FACSCalibur using CellQuest Pro software (BD Biosciences). A minimum of 10,000 events was recorded per sample. When NK cell depletion was monitored in mice, a minimum of 25,000 events were recorded per sample. The threshold between fluorescence-positive and -negative was set such that $>99.5 \%$ of WBCs incubated with control antibodies were considered negative. 


\section{Adoptive transfer of lymphocytes to BALB/c scid mice} Unfractionated and purified WBCs were obtained from naïve BALB/c donors for adoptive transfer to BALB/c scid mice, as follows. Spleens and cervical lymph nodes were removed from ten naïve $\mathrm{BALB} / \mathrm{C}$ mice and dissociated to yield a single cell suspension. WBCs were purified using Lympholyte $\mathrm{M}$ according to the manufacturer's directions (CedarLane Laboratories Ltd., Hornby, Ontario, Canada). Purified lymphocytes were obtained by passing BALB/C spleen WBCs through immunoaffinity $\mathrm{B}$ cell and $\mathrm{T}$ cell columns according to the manufacturer's directions (Cytovax Biotechnologies Inc., Edmonton, Alberta, Canada). Adoptive transfer of WBCs was achieved by intravenous (i.v.) tailvein injection of BALB/c scid mice with 0.5 $\mathrm{ml}$ complete RPMI-1640 containing nothing (vehicle), 5 $\times 10^{6}$ unfractionated WBCs (total WBCs), $5 \times 10^{6}$ purified B cells, or $5 \times 10^{6}$ purified T cells.

\section{NK cell cytotoxicity assay}

YAC- 1 cells $\left(1 \times 10^{4}\right.$ cells $)$ were labeled with ${ }^{51} \mathrm{Cr}$ and incubated with BALB/c, BALB/c scid, and NOD scid spleen WBCs in round bottom 96-well plates for 6 hours at $37^{\circ} \mathrm{C}$ at effector : target ratios of 100:1, 50:1, 25:1, 12.5:1, and $6.25: 1$ ( $n=3$ per group). One hundred microliters of supernatant were collected from each culture for determination of ${ }^{51} \mathrm{Cr}$ release from target cells. Controls for the assay included $1 \times 10^{4}$ cells target cells incubated alone in culture medium (spontaneous release) and target cells incubated with $0.5 \%$ Triton X-100 (maximal release). The percent cytotoxicity in each group of three replicate cultures was calculated, as follows:

$\%$ lysis $=100 \times \frac{\text { mean CPM release per group }- \text { mean spontaneous CPM release }}{\text { mean maximal CPM release }- \text { mean spontaneous CPM release }}$

\section{NK cell depletion and cyclophosphamide treatment}

Between days -1 and 10 p.i., BALB/c mice and BALB/c scid mice were given four to six i.p. injections of normal rabbit IgG (Rockland Immunochemicals, Gilbertsville, PA) or rabbit IgG containing anti-asialo GM1 antibody (Wako Chemicals USA, Richmond, VA). The efficacy of NK cell depletion was validated by flow cytometric comparison of NK cell $\left(\mathrm{CD}^{-} \mathrm{CD}^{-} \mathrm{Cb}^{+}\right)$frequency. Cyclophosphamide (Mead Johnson Oncology Products, Princeton, NJ) was diluted with phosphate-buffered saline (PBS) such that a volume of $0.25 \mathrm{ml}$ delivered i.p. would achieve a dose of $125 \mathrm{mg} / \mathrm{kg}$ (e.g., $11 \mathrm{mg} / \mathrm{ml}$ for $22 \mathrm{~g}$ mice). Vehicle-treated controls received $0.25 \mathrm{ml}$ PBS. Intraperitoneal injections of PBS or cyclophosphamide were administered on days $1,+1$, and +3 after viral inoculation.

\section{Statistical analysis}

Analysis of numerical data and statistical analyses were performed with the software packages Microsoft Excel (Redmond, WA) and Modstat (Modern Microcomputers, Mechanicsville, VA). Unless otherwise indicated, all data are presented as means \pm standard errors of the means (SEM). Viral titers were transformed by adding a value of 1 to the number of pfu per eye such that negative results (i.e. no plaques detected) could also be analyzed on a logarithmic scale. The significance of differences in viral titers between three or more groups was statistically evaluated by one way analysis of variance (ANOVA) followed by Tukey's post hoc t-test. The significance of differences in duration of survival between each treatment group and PBS-treated controls was evaluated by a two-way t-test.

\section{Competing interests}

The author(s) declare that they have no competing interests.

\section{Authors' contributions}

BMG carried out the scid vs NOD scid experiments and NK cell cytotoxicity assays. WPH carried out the anti-asialo GM1 and CyP depletion experiments with the assistance of JLM. JLM performed the flow cytometric analysis of spleen cells. WPH and BMG conceived of the study. WPH wrote the manuscript.

\section{Acknowledgements}

This work was supported by grants from the National Institute of Allergy and Infectious Diseases (R0I AI54 104), the National Center for Research Resources (P20 RR-020I85-0I), the National Eye Institute (R0I EY02672 and P30 EY002377), and by an unrestricted departmental grant from Research to Prevent Blindness, Inc., New York, N.Y. Dr. William Halford is supported by a National Science Foundation EPSCoR grant to Montana State University (EPS 0346458) and the Montana Agricultural Experiment Station.

\section{References}

I. Biron CA, Byron KS, Sullivan JL: Severe herpesvirus infections in an adolescent without natural killer cells. N Engl J Med I989, 320(26): $|73|-\mid 735$.

2. Dalloul A, Oksenhendler E, Chosidow O, Ribaud P, Carcelain G, Louvet S, Massip P, Lebon P, Autran B: Severe herpes virus (HSV-2) infection in two patients with myelodysplasia and undetectable NK cells and plasmacytoid dendritic cells in the blood. J Clin Virol 2004, 30(4):329-336.

3. Jawahar S, Moody C, Chan M, Finberg R, Geha R, Chatila T: Natura Killer (NK) cell deficiency associated with an epitope-deficient Fc receptor type IIIA (CDI6-II). Clin Exp Immunol I996, I 03(3):408-4 I3.

4. York IA, Roop C, Andrews DW, Riddell SR, Graham FL, Johnson DC: A cytosolic herpes simplex virus protein inhibits antigen presentation to CD8+ T lymphocytes. Cell 1994, 77:525-535.

5. Rola-Pleszczynski M: In vitro induction of human cell-mediated cytotoxicity directed against herpes simplex virus-infected cells: characterization of the effector lymphocyte. J Immunol 1980, I 25(4): | 475-1480.

6. Bishop GA, Glorioso JC, Schwartz SA: Relationship between expression of herpes simplex virus glycoproteins and susceptibility of target cells to human natural killer activity. J Exp Med 1983, I57(5):I544-I56I.

7. Fitzgerald PA, Mendelsohn M, Lopez C: Human natural killer cells limit replication of herpes simplex virus type I in vitro. I Immunol 1985, I34(4):2666-2672.

8. Huard B, Fruh K: A role for MHC class I down-regulation in NK cell lysis of herpes virus-infected cells. Eur J Immunol 2000, 30(2):509-5I 5

9. Ashkar AA, Rosenthal KL: Interleukin-I 5 and natural killer and NKT cells play a critical role in innate protection against 
genital herpes simplex virus type 2 infection. J Virol 2003, 77(18): $10168-1017 \mid$.

10. Lopez C, Kirkpatrick D, Read SE, Fitzgerald PA, Pitt J, Pahwa S, Ching $\mathrm{CY}$, Smithwick EM: Correlation between low natural killing of fibroblasts infected with herpes simplex virus type $I$ and susceptibility to herpesvirus. I Infect Dis 1983, I 47(6): 1030-1035.

II. Rager-Zisman B, Quan PC, Rosner M, Moller JR, Bloom BR: Role of NK cells in protection of mice against herpes simplex virusI infection. J Immunol 1987, I 38(3):884-888.

12. Pereira RA, Scalzo A, Simmons A: Cutting edge: A NK complexlinked locus governs acute versus latent herpes simplex virus infection of neurons. J Immunol 200 I, 166(10):5869-5873.

13. Tanigawa M, Bigger JE, Kanter MY, Atherton SS: Natural killer cells prevent direct anterior-to-posterior spread of herpes simplex virus type I in the eye. Invest Ophthalmol Vis Sci 2000, 4I(I): I32-137.

14. Janeway CA, Travers P, Walport M, Schlomchik MJ: Immunobiology. 5th edition. New York, NY, Garland Science; 200 I.

15. Parham P: The Immune System. 2nd edition. New York, NY, Garland Science; 2005

16. Biron CA: Initial and innate responses to viral infections--pattern setting in immunity or disease. Curr Opin Microbiol 1999 , 2(4):374-38I.

17. Whitton JL, Oldstone MBA: The immune response to viruses. In Fundamental Virology 4th edition. Edited by: Knipe DM, Howley PM. Philadelphia, PA , Lippincott, Williams, and Wilkins; 200I.

18. Orange JS: Human natural killer cell deficiencies and susceptibility to infection. Microbes Infect 2002, 4(I5): I545-I558.

19. Bukowski JF, Welsh RM: The role of natural killer cells and interferon in resistance to acute infection of mice with herpes simplex virus type I. J Immunol 1986, I36(9):348I-3485

20. Wu L, Morahan PS: Macrophages and other nonspecific defenses: role in modulating resistance against herpes simplex virus. Curr Top Microbiol Immunol 1992, 179:89-1 I0.

21. Engler H, Zawatzky R, Kirchner H, Armerding D: Experimental infection of inbred mice with herpes simplex virus. IV. Comparison of interferon production and natural killer cell activity in susceptible and resistant adult mice. Arch Virol 1982, 74(4):239-247.

22. Vollstedt S, Arnold S, Schwerdel C, Franchini M, Alber G, Di Santo JP, Ackermann M, Suter M: Interplay between Alpha/Beta and Gamma Interferons with B, T, and Natural Killer Cells in the Defense against Herpes Simplex Virus Type I. J Virol 2004, 78(8):3846-3850.

23. Hart PH, Bonder CS, Balogh J, Dickensheets HL, Donnelly RP, FinlayJones J]: Differential responses of human monocytes and macrophages to IL-4 and IL-13. J Leukoc Biol 1999, 66(4):575-578.

24. Girard D: Phenotypic and functional change of neutrophils activated by cytokines utilizing the common cytokine receptor gamma chain. Chem Immunol Allergy 2003, 83:64-80.

25. He YW, Malek TR: The structure and function of gamma cdependent cytokines and receptors: regulation of $T$ lymphocyte development and homeostasis. Crit Rev Immunol I998, I 8(6):503-524.

26. Ghiasi $\mathrm{H}$, Cai S, Perng GC, Nesburn AB, Wechsler SL: The role of natural killer cells in protection of mice against death and corneal scarring following ocular HSV-I infection. Antiviral Res 2000, 45(I):33-45.

27. Slifka MK, Pagarigan RR, Whitton JL: NK markers are expressed on a high percentage of virus-specific CD8+ and CD4+ T cells. J Immunol 2000, 164(4):2009-20I5.

28. Halford WP, Halford KJ, Pierce AT: Mathematical analysis demonstrates that interferons-beta and -gamma interact in a multiplicative manner to disrupt herpes simplex virus replication. J Theor Biol 2005, 234:439-454.

29. Pierce AT, Desalvo J, Foster TP, Kosinski A, Weller SK, Halford WP. Interferon-beta and interferon-gamma synergize to block viral DNA and virion synthesis in herpes simplex virusinfected cells. Submitted 2005.

30. Luker GD, Prior JL, Song J, Pica CM, Leib DA: Bioluminescence imaging reveals systemic dissemination of herpes simplex virus type $I$ in the absence of interferon receptors. J Virol 2003, 77(20): I I082-II093.

31. Halford WP, Schaffer PA: Optimized viral dose and transient immunosuppression enable herpes simplex virus ICP0-null mutants to establish wild-type levels of latency in vivo. J Virol 2000, 74(1 3):5957-5967.

32. Farrar MA, Schreiber RD: The molecular cell biology of interferon-gamma and its receptor. Annu Rev Immunol 1993, I I:57|-6III.

33. Suzue $\mathrm{K}$, Asai T, Takeuchi T, Koyasu S: In vivo role of IFN-gamma produced by antigen-presenting cells in early host defense against intracellular pathogens. Eur J Immunol 2003, 33(10):2666-2675

34. Cantin E, Tanamachi B, Openshaw H: Role for gamma interferon in control of herpes simplex virus type I reactivation. J Virol 1999, 73(4):3418-3423.

35. Cantin E, Tanamachi B, Openshaw H, Mann J, Clarke K: Gamma interferon (IFN-gamma) receptor null-mutant mice are more susceptible to herpes simplex virus type I infection than IFN-gamma ligand null-mutant mice. J Virol 1999, 73(6):5196-5200

36. Liu T, Khanna KM, Chen X, Fink DJ, Hendricks RL: CD8(+) T cells can block herpes simplex virus type I (HSV-I) reactivation from latency in sensory neurons. I Exp Med 2000, I 9 I(9): | 459- | 466

37. Liu T, Khanna KM, Carriere BN, Hendricks RL: Gamma interferon can prevent herpes simplex virus type I reactivation from latency in sensory neurons. J Virol 200I, 75(22): I I I78-I I I 84.

38. Theil D, Derfuss T, Paripovic I, Herberger S, Meinl E, Schueler O, Strupp M, Arbusow V, Brandt T: Latent herpesvirus infection in human trigeminal ganglia causes chronic immune response. Am J Pathol 2003, 163(6):2179-2184.

39. Aaronson DS, Horvath CM: A road map for those who don't know JAK-STAT. Science 2002, 296(5573): 1653-1655.

40. Levy DE, Darnell JE]: Stats: transcriptional control and biological impact. Nat Rev Mol Cell Biol 2002, 3(9):65I-662.

4I. Hendrickson EA: The SCID mouse: relevance as an animal model system for studying human disease. Am J Pathol 1993 , I43(6): I5II-I522.

42. Mosier DE, Stell KL, Gulizia RJ, Torbett BE, Gilmore GL: Homozygous scid/scid;beige/beige mice have low levels of spontaneous or neonatal T cell-induced B cell generation. J Exp Med 1993, I77(1): I9I-194.

43. Nonoyama S, Smith FO, Bernstein ID, Ochs HD: Strain-dependent leakiness of mice with severe combined immune deficiency. J Immunol 1993, I 50(9):3817-3824.

44. Shultz LD, Schweitzer PA, Christianson SW, Gott B, Schweitzer IB, Tennent B, McKenna S, Mobraaten L, Rajan TV, Greiner DL, et al.: Multiple defects in innate and adaptive immunologic function in NOD/LtSz-scid mice. J Immunol I995, I 54(I): I80-191.

45. Gombert JM, Herbelin A, Tancrede-Bohin E, Dy M, Carnaud C, Bach JF: Early quantitative and functional deficiency of NKI+-like thymocytes in the NOD mouse. Eur J Immunol 1996, 26(I 2):2989-2998.

46. Hussell T, Openshaw PJ: Intracellular IFN-gamma expression in natural killer cells precedes lung CD8+ $T$ cell recruitment during respiratory syncytial virus infection. J Gen Virol 1998, 79(Pt II)):2593-260I

47. Arase H, Saito T, Phillips JH, Lanier LL: Cutting edge: the mouse NK cell-associated antigen recognized by DX5 monoclonal antibody is CD49b (alpha 2 integrin, very late antigen-2). J Immunol 200I, 167(3): I|4|-II44.

48. Turk JL, Poulter LW: Effects of cyclophosphamide on lymphoid tissues labelled with 5-iodo-2-deoxyuridine- I 25 I and 5 I Cr. Int Arch Allergy Appl Immunol I972, 43(4):620-629.

49. Stockman GD, Heim LR, South MA, Trentin JJ: Differential effects of cyclophosphamide on the $B$ and $T$ cell compartments of adult mice. J Immunol I 973, I I O(I):277-282.

50. Halford WP, Balliet JD, Gebhardt BM: Re-evaluating natural resistance to herpes simplex virus type I. J Virol 2004 , 78(I 8): 10086-10095

5I. Ellison AR, Yang L, Voytek C, Margolis TP: Establishment of latent herpes simplex virus type I infection in resistant, sensitive, and immunodeficient mouse strains. Virology 2000, 268(1):17-28

52. Heyman B: Feedback regulation by IgG antibodies. Immunol Lett 2003, 88(2):|57-|6|.

53. Ward ES, Zhou J, Ghetie V, Ober RJ: Evidence to support the cellular mechanism involved in serum IgG homeostasis in humans. Int Immunol 2003, I5(2): I87-195. 
54. Kurosaka K, Watanabe N, Kobayashi Y: Potentiation by human serum of anti-inflammatory cytokine production by human macrophages in response to apoptotic cells. J Leukoc Biol 2002, 7 I(6): $950-956$.

55. Nagashunmugam T, Lubinski J, Wang L, Goldstein LT, Weeks BS, Sundaresan $P$, Kang EH, Dubin G, Friedman HM: In vivo immune evasion mediated by the herpes simplex virus type I immunoglobulin G Fc receptor. J Virol I998, 72(7):535I-5359.

56. Vollstedt S, Franchini M, Hefti HP, Odermatt B, O'Keeffe M, Alber G, Glanzmann B, Riesen M, Ackermann M, Suter M: Flt3 ligandtreated neonatal mice have increased innate immunity against intracellular pathogens and efficiently control virus infections. J Exp Med 2003, 197(5):575-584.

57. Franchini M, Hefti $H$, Vollstedt $S$, Glanzmann B, Riesen M, Ackermann M, Chaplin P, Shortman K, Suter M: Dendritic cells from mice neonatally vaccinated with modified vaccinia virus Ankara transfer resistance against herpes simplex virus type I to naive one-week-old mice. J Immunol 2004, I72(10):6304-63II.

58. Johnson HM, Subramaniam PS, Olsnes S, Jans DA: Trafficking and signaling pathways of nuclear localizing protein ligands and their receptors. Bioessays 2004, 26(9):993-1004.

59. Lucin P, Jonjic S, Messerle M, Polic B, Hengel H, Koszinowski UH: Late phase inhibition of murine cytomegalovirus replication by synergistic action of interferon-gamma and tumour necrosis factor. J Gen Virol I994, 75(Pt I): I0I-IIO.

60. Desloges N, Rahaus M, Wolff MH: Role of the protein kinase PKR in the inhibition of varicella-zoster virus replication by beta interferon and gamma interferon. J Gen Virol 2005, 86(Pt I): I-6.

6I. Sainz BJ, Halford WP: Alpha/Beta interferon and gamma interferon synergize to inhibit the replication of herpes simplex virus type I. J Virol 2002, 76(22): I I54I-I I 550.

62. Sainz B], Lamarca HL, Garry RF, Morris CA: Synergistic inhibition of human cytomegalovirus replication by interferon-alphal beta and interferon-gamma. Virol J 2005, 2(I): 14.

63. Hill A, Jugovic P, York I, Russ G, Bennink J, Yewdell J, Ploegh H, Johnson $D$ : Herpes simplex virus turns off the TAP to evade host immunity. Nature 1995, 375:4||-4I5.

64. Tomazin R, van Schoot NE, Goldsmith K, Jugovic P, Sempe P, Fruh K, Johnson DC: Herpes simplex virus type 2 ICP47 inhibits human TAP but not mouse TAP. J Virol 1998, 72(3):2560-2563.

65. Smith KO: Relationship between the envelope and the infectivity of herpes simplex virus. Proc Soc Exp Biol Med 1964, I I5:8|4-8|6.

\section{Publish with Bio Med Central and every scientist can read your work free of charge}

"BioMed Central will be the most significant development for disseminating the results of biomedical research in our lifetime. "

Sir Paul Nurse, Cancer Research UK

Your research papers will be:

- available free of charge to the entire biomedical community

- peer reviewed and published immediately upon acceptance

- cited in PubMed and archived on PubMed Central

- yours - you keep the copyright
BioMedcentral 